OPEN ACCESS

Edited by:

Paula Chiarella,

Academia Nacional de Medicina,

Argentina

Reviewed by:

Jareer Kassis,

Bien-Etre Labs LLS, United States

Paola Massimi

International Centre for Genetic

Engineering and Biotechnology, Italy

${ }^{*}$ Correspondence:

Pushpa Pandiyan

pxp226@case.edu

${ }^{\dagger}$ These authors have contributed equally to this work

Specialty section:

This article was submitted to Molecular and Cellular Oncology,

a section of the journal

Frontiers in Oncology

Received: 17 February 2021

Accepted: 06 April 2021

Published: 22 April 2021

Citation:

Bhaskaran N, Jayaraman S, Quigley C,

Mamileti $P$, Ghannoum M,

Weinberg A, Thuener J, Pan $Q$ and

Pandiyan P (2021) The Role

of Dectin-1 Signaling in Altering

Tumor Immune Microenvironment

in the Context of Aging.

Front. Oncol. 11:669066.

doi: 10.3389/fonc.2021.669066

\section{The Role of Dectin-1 Signaling in Altering Tumor Immune Microenvironment in the Context of Aging}

\author{
Natarajan Bhaskaran ${ }^{1 \dagger}$, Sangeetha Jayaraman ${ }^{1 \dagger}$, Cheriese Quigley ${ }^{1}$, Prerna Mamileti ${ }^{1}$, \\ Mahmoud Ghannoum ${ }^{2,3}$, Aaron Weinberg ${ }^{1,4}$, Jason Thuener ${ }^{5}$, Quintin Pan ${ }^{2,5}$ \\ and Pushpa Pandiyan ${ }^{1,2,4 *}$
}

1 Department of Biological Sciences, School of Dental Medicine, University Hospitals Cleveland Medical Center, Cleveland, $\mathrm{OH}$, United States, 2 Department of Pathology, University Hospitals Cleveland Medical Center, Cleveland, OH, United States, ${ }^{3}$ Dermatology, School of Medicine, University Hospitals Cleveland Medical Center, Cleveland, OH, United States,

${ }^{4}$ Case Comprehensive Cancer Center, Case Western Reserve University, University Hospitals Cleveland Medical Center, Cleveland, $\mathrm{OH}$, United States, ${ }^{5}$ Otolaryngology-Head and Neck surgery, University Hospitals Cleveland Medical Center, Cleveland, $\mathrm{OH}$, United States

An increased accumulation of immune-dysfunction-associated $\mathrm{CD}^{+}{ }^{+} \mathrm{Foxp} 3^{+}$regulatory $\mathrm{T}$ cells $\left(T_{\text {regs }}\right)$ is observed in aging oral mucosa during infection. Here we studied the function of $T_{\text {regs }}$ during oral cancer development in aging mucosa. First, we found heightened proportions of $\mathrm{T}_{\text {regs }}$ and myeloid-derived suppressor cells (MDSC) accumulating in mouse and human oral squamous cell carcinoma (OSCC) tissues. Using the mouse 4Nitroquinoline 1-oxide(4-NQO) oral carcinogenesis model, we found that tongues of aged mice displayed increased propensity for epithelial cell dysplasia, hyperplasia, and accelerated OSCC development, which coincided with significantly increased abundance of IL-1 $\beta, T_{\text {regs }}$, and MDSC in tongues. Partial depletion of $T_{\text {regs }}$ reduced tumor burden. Moreover, fungal abundance and dectin-1 signaling were elevated in aged mice suggesting a potential role for dectin-1 in modulating immune environment and tumor development. Confirming this tenet, dectin-1 deficient mice showed diminished IL-1 $\beta$, reduced infiltration of $T_{\text {regs }}$ and MDSC in the tongues, as well as slower progression and reduced severity of tumor burden. Taken together, these data identify an important role of dectin-1 signaling in establishing the intra-tumoral immunosuppressive milieu and promoting OSCC tumorigenesis in the context of aging.

Keywords: $\mathrm{T}_{\text {reg, }}$ Foxp3, Treg17, IL-1 $\beta$, Candida, oral cancer, tumorigenesis, aging

\section{INTRODUCTION}

Head and neck cancers (HNC) including OSCC are the sixth most common cancers, accounting for an estimated 657,000 new cases and more than 330,000 deaths globally each year. The aging population (age $>65$ ) has grown to 727 million in 2020 and will double to nearly 1.5 billion, roughly $\sim 16 \%$ of the world population by 2050 . A majority of all new cancers are diagnosed among elderly adults (1). Therefore, the convergence of the aging population and a higher cancer incidence in this 
population will result in a significant rise in cancer. Aging triggers the immune system to be in a chronic hyperinflammatory state known as inflammaging. An imbalance between pro- and anti-inflammatory mechanisms due to the combination of inflammaging and impaired immunesurveillance may contribute to increased susceptibility of elderly individuals to cancer (2-4). However, precise cellular alterations in the tumor immune microenvironment (TIME) that contribute to tumor growth and progression in the elderly are not completely understood. HNC are among the most highly immune-cell infiltrated cancer types, highlighting the significance of immune cells in tumor development and progression blockade. Immune-suppressive cells including $\mathrm{T}_{\text {regs }}$, MDSC, and tumor-associated macrophages (TAM) that are important in immune tolerance, accumulate in tumors, and are thought to contribute to poor immunologic responses against tumors resulting in cancer immune evasion (5-14). Depending on the tumor type, $\mathrm{T}_{\text {regs }}$ may constitute between $30-45 \%$ of $\mathrm{CD}^{+} \mathrm{T}$ cells in solid tumors of nonlymphoid origin, with OSCC cancers having the highest degrees of $\mathrm{T}_{\text {reg }}$ infiltration $(15,16)$. $\mathrm{T}_{\text {regs }}$ and MDSC have been shown to contribute to tumor evasion and even hinder the success of $\alpha$-PD1 cancer immunotherapy (17-20). Thus there is considerable interest in understanding the involvement of these cells in many cancers (21-25). However, molecular mechanisms that instruct intra-tumoral $\mathrm{T}_{\text {reg }}$ recruitment, proliferation, stability, or functions in the context of their interactions with anti-tumor CD8 cells and other immune-suppressive cells remain elusive. Understanding these mechanisms will lead to new combinatorial strategies in the face of PD-1/PD-L1 blockade resistance, leading to improved patient outcomes. Having previously linked some of the immunosenescent cytokines in $\mathrm{T}_{\text {reg }}$ accrual and aging previously (26), we now show that dectin-1 signaling is required for increased IL-1 $\beta$, MDSC, and $\mathrm{T}_{\text {regs }}$ during carcinogenesis, and that this enhancement in aged mice contributes to the acceleration in tumor development in them.

\section{MATERIALS AND METHODS}

\section{Mice and Human Samples}

Mouse experiments were performed following all guidelines and regulations under an approval from the CWRU Institutional Animal Care and Use Committee. Young (3-4 months of age), aged (20-24 months of age) C57BL/6 mice, TLR- $2^{-/-}$and Dectin$1^{-/-}$mice were purchased from Jackson laboratories. Human oral tissue samples were obtained by excision (tumor resection), cytobrushing (mostly epithelial cells), or by biopsy (control tissue $2-3 \mathrm{~cm}$ from the tumor margin) under an approved protocol approved by the University Hospitals Cleveland Medical Center Institutional Review Board.

\section{4-NQO Administration in Mice}

4-NQO was dissolved in 1:1 solution of propylene glycol and DMSO and administrated in drinking water $(50-100 \mu \mathrm{g} / \mathrm{ml})$ for
16 weeks, followed by the regular drinking water for another 6 weeks. Mice were sacrificed at the end of 24-25 week 4-NQO regimen. Young mice developed OSCC tumors after 24- 25 weeks and aged mice around 21-22 weeks after the start of 4NQO administration (Figure 1A). Control mice received the propylene glycol/DMSO vehicle. Mouse body weight was measured every other day until sacrifice. 5-, 12 and 15- week time-points were considered early timepoints for the evaluation of immune cell changes in the tongue. Scores were assigned using tongue immuno-histochemistry using established OSCC criteria (27). Epithelial hyperplasia and dysplasia scores were designated at 12 weeks after the 4 -NQO regimen as follows: $0=$ No immune infiltrates and the presence of cohesive epithelium; 1 = Sparse immune infiltrates with mild epithelial hyperplasia; $2=$ Sparse immune infiltrates and moderate epithelial hyperplasia and dysplasia; 3 = Severe epithelial hyperplasia and dysplasia and moderate hyperkeratosis; 4 = Severe epithelial hyperplasia and dysplasia and hyperkeratosis; $5=$ Presence of invasive hyperkeratosis. OSCC scores were given at 20 or 24-25 weeks after the 4-NQO regimen as follows: $0=$ No immune infiltrates and the presence of cohesive epithelium; $1=$ Sparse immune infiltrates with mild epithelial hyperplasia; $2=$ Moderate epithelial hyperplasia and dysplasia; $3=$ Severe epithelial hyperplasia and dysplasia and moderate hyperkeratosis; $4=$ Severe epithelial hyperplasia and dysplasia and hyperkeratosis; $5=$ Presence of invasive hyperkeratosis, cell nests and OSCC.

\section{Antibodies}

Purified or fluorochrome conjugated mouse and human $\alpha$-CD25 (3C7 and 7D4), CD4, IFN- $\gamma$, Foxp3, CD45, CD8, CD11C, CD38, HLADR, Phospho-Syk (Ser473), IL-1 $\beta$, IL-6, Arg-1, PerCPeFluor 710 conjugated Ly-6G Monoclonal Antibody (1A8Ly6g), APC conjugated CD11b Monoclonal Antibody (M1/70) and dectin-1 antibodies were all purchased from Life Technologies/Thermofisher and BD-Biosciences.

\section{Quantitative-PCR}

DNA was isolated from mouse saliva swabs using the PureLink ${ }^{\mathrm{TM}}$ Microbiome DNA Purification Kit (Invitrogen). ITS and FungiQuant qPCR primers $(28,29)$ (Invitrogen), and SYBR Green PCR Kit (BioBasic) were used for performing qPCR, employing the real time PCR machine (Applied Biosystems). The relative amount of fungal DNA of interest was estimated from its $\mathrm{Ct}$ values, which were normalized to the host $\beta$-actin DNA levels.

\section{Histochemistry and Immunohistochemistry of Proteins}

For immunocytochemical hematoxylin and eosin (H\&E), and immuno-histochemistry staining, tongue tissues were rinsed with PBS, fixed with 10\% formalin overnight, and rehydrated in $70 \%$ ethanol overnight for paraffin embedding. This was followed by paraffin-sectioning and staining by the commercial facility (Histoserv, Inc, MD). Antibodies were used at $1-5 \mu \mathrm{g} / \mathrm{ml}$ concentrations. 


\section{Flow Cytometry and ELISA}

Cells were re-stimulated with PMA (50 ng/ml) and Ionomycin (500 ng/ml) for 4 hours in complete RPMI-1640 (Hyclone) supplemented with $10 \% \mathrm{FCS}, 100 \mathrm{U} / \mathrm{ml}$ penicillin, $100 \mu \mathrm{g} / \mathrm{ml}$ streptomycin, $2 \mathrm{mM}$ glutamine, $10 \mathrm{mM}$ HEPES, $1 \mathrm{mM}$ sodium pyruvate and $50 \mu \mathrm{M} \beta$-mercaptoethanol (30). Brefeldin-A $(10 \mu \mathrm{g} / \mathrm{ml})$ added in last 2 hours before harvesting the cells and supernatants. For single-cell flow cytometry staining, cells washed in PBS or PBS/BSA before surface and intracellular staining. Live-Dead viability staining was used to remove dead cells in the flow cytometry analyses. Appropriate un-stain, isotype, secondary antibody, single stain and FMO controls were used. For p-Syk staining, the cells were washed, fixed and were stained with Phosflow staining kit from BD Biosciences using manufacturer's protocol. For examining T cells, leukocyte singlets, Live-dead ${ }^{\text {neg }}, \mathrm{CD}_{4} 5^{+} \mathrm{CD} 3^{+} \mathrm{CD} 4^{+}$or $\mathrm{CD} 8^{+}$gates were used. For examining MDSC, leukocyte singlets, Live-dead ${ }^{\text {neg }}$, $\mathrm{CD} 45^{+} \mathrm{CD} 3^{\text {neg }}$ gates were used. Data was acquired using BD Fortessa cytometers and were analyzed using FlowJo 9.8 or 10.5.3 software. Mouse IL-1 $\beta$ and IL-6 ELISA kits from Boster Bio (Pleasanton, CA) were used to assess the protein levels in the supernatants.

\section{Oral Candida Infection and Zymosan Application}

Mice were infected with Candida as previously described (31, 32). Briefly, they were sublingually applied under anesthesia by placing a $3 \mathrm{~mm}$ diameter cotton ball saturated with $1 \times 10^{7}$ Candida albicans (SC5314) blastospores for $90 \mathrm{~min}$. Mice were

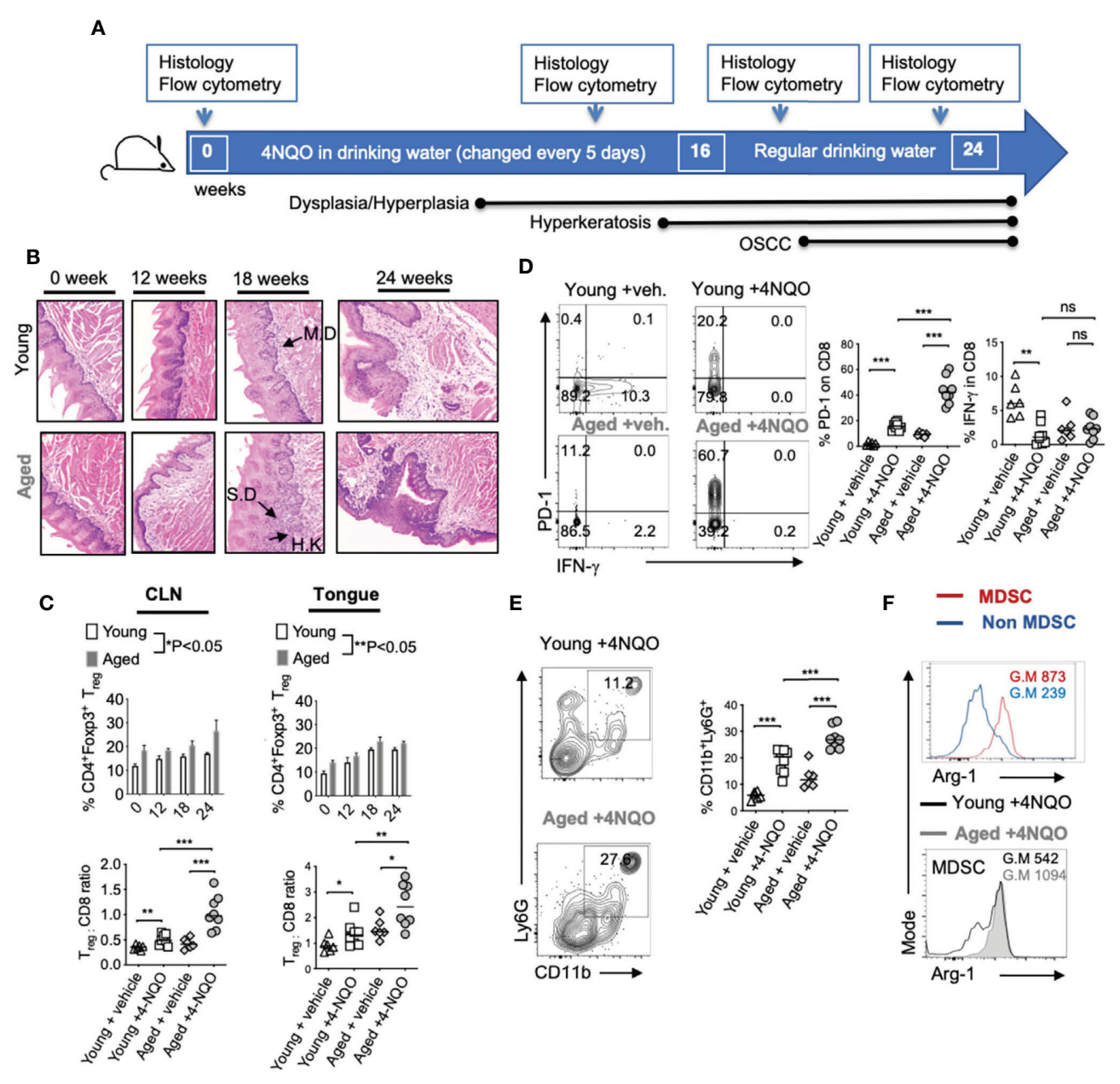

FIGURE 1 | Aged mice display accelerated development of OSCC and heightened levels of immunosuppressive cells in the tongue. 4-NQO was (50 $\mu \mathrm{g} / \mathrm{ml})$ administered in drinking water. Time-points for readouts and various stages of OSCC development in this model are shown (A). H\&E immunohistochemistry images of the tong15ue at 200X magnification at indicated times [IF, Infiltration; MD, mild dysplasia; SD, severe dysplasia/hyperplasia; HK, Hyperkeratosis]. Samples were processed for flow cytometry (B). Statistics showing \% $\mathrm{T}_{\text {regs }}\left(\mathbf{C}\right.$, top) and $\mathrm{T}_{\text {reg: }}$ :CD8 ratio (C, bottom) in the draining cervical lymph nodes (CLN) (left), or tongue (right) at 16 weeks (D). Contour plots (left) and statistics (right) showing \% of PD-1 and IFN- $\gamma$ expressing CD8 ${ }^{+}$cells (E). Representative contour plots (left) and statistics (right) showing \% of

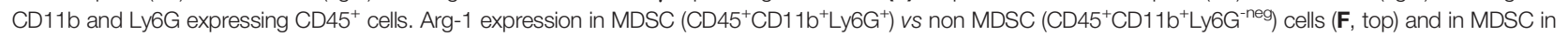
young and aged 4-NQO treated mice (F, bottom) (Geometric Mean = G.M) (Mann-Whitney test ${ }^{\star} P<0.05,{ }^{\star \star} P<0.05,{ }^{* \star *} P<0.005$; n.s, non-significant). 
re-infected as indicated. We applied Zymosan sublingually in the same manner (33).

\section{Statistical Analysis}

Results represent at least two to three independent experiments. $\mathrm{P}$ values were calculated by Mann-Whitney test in Prism 6.1 (GraphPad Software, Inc.) assuming random distribution. Welch's correction and student $t$ tests were used where indicated. One or two way ANOVA analyses were also used for grouped analyses. $\mathrm{P}<0.05^{\star}$ was considered significant.

\section{RESULTS}

\section{Aged Mice Show Earlier and Exacerbated Dysplasia/Hyperplasia, and OSCC Development as well as Heightened Levels of Immunosuppressive Cells in the Tongue}

To obtain mechanistic insights into immunological changes driving OSCC and to define aging-dependent alterations in early immunological events during carcinogenesis, we used the 4-NQO oral carcinogenesis mouse model. This constitutes 16weeks of 4-NQO administration in drinking water followed by another 6-weeks with regular drinking water (Figure 1A). We compared young (3-4 months of age) and aged (20-24 months of age) C57BL/6 mice treated with 4-NQO. Control mice received the propylene glycol vehicle in drinking water. At indicated times, we examined the tongue pathology by immunohistochemistry using established OSCC criteria (Figure 1B). Thickened keratinized layer (Hyperkeratosis; HK), lesions showing enlarged nuclei with increased nuclear to cytoplasmic ratio, loss of typical epithelial cell organization (dysplasia), intrusion into the connective tissue, and presence of cell nests were used for scoring on a 0-5 scale. Aged mice demonstrated earlier and higher incidence of accelerated progression of hyperkeratosis, hyperplasia, and dysplasia during early time points (12- 22 weeks) (Figure 1B). Also, more mice in the aged group showed these changes at early time-points (Figure S1). These data are consistent with a previous study that elegantly showed similar results in aged mice (34). Since agingrelated differences in OSCC were not significant after 23-24 weeks, we focused on early events of carcinogenesis in defining altered and accelerated dysplasia in aging mice. Therefore, we examined the rest of the parameters at this early time (12- 16 weeks) window. We isolated the tongue/gingival tissues and the oral draining cervical lymph nodes (CLN) and determined the frequency of $\mathrm{CD} 3^{+} \mathrm{CD} 4^{+} \mathrm{Foxp}^{+} \mathrm{T}_{\text {regs }}$ by flow cytometry $(\mathrm{n}=6 /$ Veh. group; $\mathrm{n}=8 / 4-\mathrm{NQO}$ group). 4-NQO carcinogenesis process also increased the frequency of Foxp $3^{+} \mathrm{T}_{\text {regs }}$ in oral tissues and draining lymph nodes, which increased with time (Figure 1C, S2). Aged mice displayed significantly higher proportions of $\mathrm{T}_{\text {regs }}$ when compared to younger mice (Figure 1C). Correlating with the increase in $\mathrm{T}_{\text {regs }}$, the percentage of $\mathrm{CD}^{+} \mathrm{CD}^{+}$cells decreased, and the aged mice had a significantly higher $\mathrm{T}_{\text {reg: }}$ : $\mathrm{CD} 8$ ratio than young mice (Figure 1D, left). $\mathrm{CD} 8{ }^{+} \mathrm{T}$ cells in the tongue also upregulated PD-1 but showed a decreased expression of IFN- $\gamma$ in 4-NQO treated mice in both groups (Figure 1D, right). Also, tongues from $4-\mathrm{NQO}$ treated mice showed increased accumulation of $\mathrm{CD} 11 \mathrm{~b}^{+} \mathrm{Ly}_{6} \mathrm{G}^{+} \mathrm{MDSC}$ cells that were at higher levels in aged mice than young mice (Figure 1E). Consistent with their MDSC phenotype, CD $11 b^{+} \mathrm{Ly}_{6 \mathrm{G}^{+}}$cells were Arginase- $1^{\text {high }}$ (Arg-1), when compared to CD11 ${ }^{+} \mathrm{Ly}_{6} \mathrm{G}^{-}$cells (Figure 1F, top). Moreover, the expression of Arg-1 was much more elevated in aged 4-NQO mice than young 4-NQO mice (Figure 1F, bottom). Thus, earlier epithelial dysplasia coincided with an increased $\mathrm{T}_{\text {regs: }} \mathrm{CD} 8$ ratio and $\mathrm{CD} 11 \mathrm{~b}^{+} \mathrm{Ly}_{6 \mathrm{G}}{ }^{+}$Arg- $1^{\text {high }}$ MDSC in aged tongues. Taken together, these results show that aging in the context of the carcinogen $4 \mathrm{NQO}$, causes premature development of oral carcinogenesis, which is associated with increased infiltration of immune-suppressive cells.

\section{Heightened Levels of Intra-Tumoral $\mathrm{T}_{\text {regs, }}$ MDSC, and IL-1 $\beta$ in OSCC Patients}

To validate 4-NQO findings, we examined surgically excised human OSCC tumors, control biopsies that included tissue derived from a site $2-3 \mathrm{~cm}$ from the tumor margin, as well as tumor lesion cytobrushings and contralateral control tissue cytobrushings from patients (Figures 2A, S3). Tumor tissues were obtained from 16 patients that included eight former smokers, four current smokers, and four non-smokers. Similar to 4-NQO treated mice, human OSCC tumors showed very high proportions of CD $25^{+}$Foxp $3^{+} \mathrm{T}_{\text {reg }}$ cells, (sometimes up to $42 \%$; Mean 22\%) (Figure 2B). This was significantly higher than what is found in gingival mucosa of healthy individuals $\left({ }^{*} \mathrm{P}<0.05\right)(26)$. Among $\mathrm{CD} 5^{+}$cells, there were also higher proportions of $\mathrm{CD}_{14}{ }^{\text {neg }} \mathrm{CD} 11 \mathrm{~B}^{+} \mathrm{CD} 33^{+}$MDSC cells (Figure 2C), which had higher ARG-1 expression, compared to non-MDSC cells (Figure 2D). Because IL-1 $\beta$ signaling is critical for induction of immunomodulatory ROR- $\gamma \mathrm{t}^{+} \mathrm{FOXP} 3^{+}$cells in oral mucosal tissues and is implicated in oral tumor progression $(26,35,36)$, we examined the expression of IL-1 $\beta$. IL-1 $\beta$ was significantly increased in the supernatants derived from human tumors and resected tumor supernatants (Figure 2E), as well as in immune cells (Figure 2F). However, the IL-1 receptor antagonist (IL1RA) levels were significantly lower in tumor samples (Figure S4) suggesting that IL-1 antagonism is associated with health while IL-1 $\beta$ was associated with tumor development. Notably, MDSC cells showed heightened levels of IL-1 $\beta$ than other cells, implying that IL-1 $\beta$ is likely linked to immune-suppressive milieu in tumors (Figure 2F).

\section{Aged Mice Have a Distinct $T_{\text {reg }}$ Phenotype and Elevated Levels of IL-1 $\beta$ Compared to Young Mice}

The degree of phenotypic and functional heterogeneity of tissue/ intra-tumoral $\mathrm{T}_{\text {regs }}$ can be high (37), and evaluating them solely with FOXP3 and CD25 markers without examining anti-tumor $\mathrm{CD}^{+} \mathrm{T}$ cells can sometimes be misleading. Besides recruiting thymic $\mathrm{T}_{\text {regs }}$ into tumors via chemotaxis, $\mathrm{T}_{\text {regs }}$ can be induced in situ in tumors due to the abundance of mediators such as nitric oxide synthase, indoleamine 2, 3-dioxygenase 1, transforming growth factor- $\beta 1$, and adenosine released from tumor cells, 


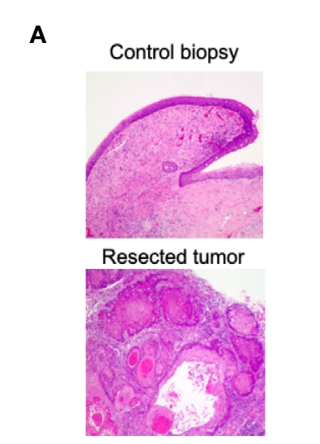

D Non MDSC: CD14 $14^{\text {neg } C D 11 B ~} 11{ }^{+} C D 33^{\text {neg }}$
MDSC: CD14

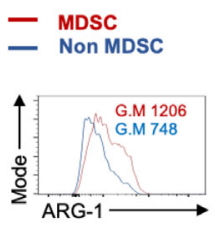

B

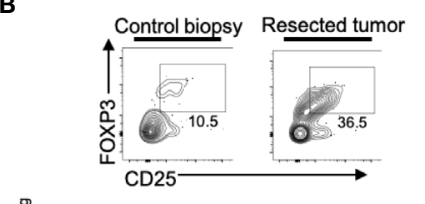

$\Delta 0$

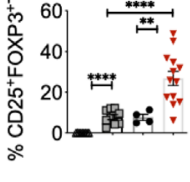

E

$\Delta$ Contralateral normal tissue cytobrush

- Tumor lesion cytobrush

- Control biopsy

- Excised tumor

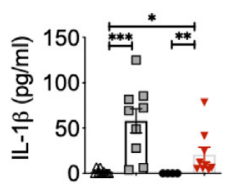

Control biopsy Resected tumor
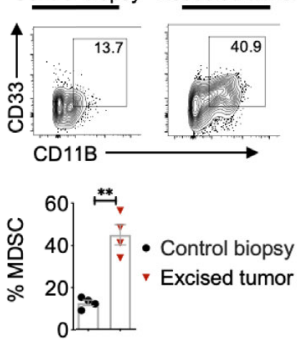

F MDSC Non MDSC $\mathrm{CD}^{+}$

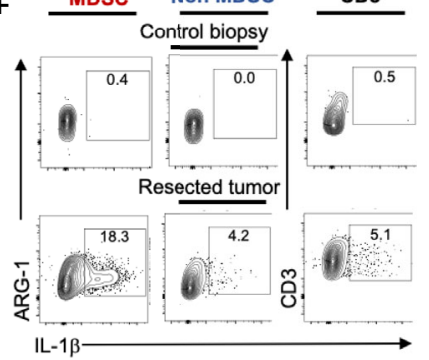

FIGURE 2 | Heightened levels of intra-tumoral $T_{\text {regs, }}$ MDSC, and IL-1 $\beta$ in OSCC patients. Human oral tissue samples were obtained by excision (tumor resection), cytobrushing (mostly epithelial cells), or by biopsy (control tissue 2-3 cm from the tumor margin) under an approved IRB protocol. H\&E immunohistochemistry images of the tongue at 200X magnification (A). Samples were digested by collagenase-1A and restimulated with PMA/lonomycin for 4 hours. Contour plots gated on $\mathrm{CD}_{4} 5^{+} \mathrm{CD}^{+} \mathrm{CD}^{+}$lymphocytes (B, top) and statistical analysis (B, bottom) showing \% of $\mathrm{T}_{\text {regs }}$ and MDSC (C). ARG-1 expression in MDSC vs non-MDSC cells (D). Supernatants were collected from these cultures and assessed for IL-1 $\beta$ using ELISA (E). Contour plots showing IL-1 $\beta$ expressing MDSC (left), non-MDSC (middle), and T cells (right) (F). Mean $+/$-SEM are shown. (Mann-Whitney test ${ }^{*} P<0.05,{ }^{* \star} P<0.05,{ }^{* \star *} P<0.005,{ }^{* \star \star *} P<0.0005$ ).

TAM, and MDSC (38). Some of these FOXP3 ${ }^{+}$cells may also be critical for tissue repair or become dysfunctional depending on the inflammatory cytokine milieu (39). Indeed we (26, 31, 40-43) and others have shown distinct functions of T-bet ${ }^{+}$Foxp $3^{+}$cells, ROR- $\gamma \mathrm{t}^{+}$Foxp $3^{+}$cells, and PD- $1^{+}$Foxp $3^{+}$cells, whose functions are significantly altered by cytokines including IL- 6 and IL- $1 \beta$ in an mTOR dependent manner in oral mucosa (26). Since CD25, PD-1, T-bet, ROR- $\gamma$ t, Suppression of Tumorigenicity 2 (ST-2) expression were all implicated in determining intra-tumoral $\mathrm{T}_{\text {reg }}$ functions positively and negatively in other tissues $(7,35,44,45)$, we examined the expression of the molecules, in aged vs. young $\mathrm{T}_{\text {regs }}, 16$ weeks after 4-NQO administration. While the expression of CD25 (ability to consume IL-2) (10, 30), Ki-67 (proliferation), and ST-2 (tissue $\mathrm{T}_{\text {reg }}$ and tumorigenicity marker) (7) did not change between young and aged $\mathrm{T}_{\text {regs }}$, CD103 (TGF$\beta 1$ dependent, tolerogenic, and tumor-specific $\mathrm{T}$ cell marker) (46), PD-1, ROR- $\gamma$ t, and T-bet were significantly up-regulated in aged $\mathrm{T}_{\text {regs }}$ (Figure 3A). Consistent with the higher expression of ROR- $\gamma \mathrm{t}$ in $\mathrm{T}_{\text {regs }}$ and earlier dysplasia in aging mice, increased numbers of IL-1 $\beta$ expressing cells were found among infiltrating immune cells in aged mice as early as 5 and 12 weeks after 4NQO administration (Figures 3B, C). IL-6 levels were also elevated in aged tongue supernatants (Figure S5). Moreover, at later times, IL-1 $\beta$ expression was found in epithelial tumor cells and immune cell infiltrates in both the groups, but was dramatically elevated in aged 4-NQO treated mice when compared to their young counterparts (Figure 3D). These results showed that $\mathrm{T}_{\text {regs }}$ found in tongues during early tumor development in 4-NQO treated mice are phenotypically distinct, appearing to be functionally more immunosuppressive in aged mice, and may be linked to higher expression of IL-1 $\beta$ in the milieu.

\section{Partial $T_{\text {reg }}$ Depletion Reduces Tumor Progression}

Although tumorigenesis coincides with increases in Foxp $3^{+} \mathrm{T}_{\text {regs }}$, the function of these cells has not been validated in the 4-NQO model. Therefore, we employed Foxp $3^{\text {DTR }}$-eGFP reporter (Foxp3 diphtheria toxin receptor; FDTR) mice that express the diphtheria toxin receptor on Foxp $3^{+}$cells and allow targeted $\mathrm{T}_{\text {reg }}$ depletion by intraperitoneal diphtheria toxin (DT) injection (20 $\mu \mathrm{g} / 10$ gm body weight; $\mathrm{n}=4$ /group) $(30,31)$. We took two approaches; 1) Early and long-term $\mathrm{T}_{\text {reg }}$ depletion where DT was injected every 5 days, in the first 16 weeks of 4-NQO treatment 2) Late and short-term $\mathrm{T}_{\text {reg }}$ depletion where DT was injected every 5 days, from the $16^{\text {th }}-21^{\text {st }}$ weeks of 4 -NQO treatment $n=6 /$ group) (Figure 4A). Early $\mathrm{T}_{\text {reg }}$ depletion caused systemic autoimmunity characterized by splenomegaly, lymphadenopathy, CD4 hyperactivation (CD $44^{\text {high }}$, IFN- $\gamma^{\text {high }}$ ), and mortality in $30 \%$ of mice which confounded the effects on early tumorigenesis (not shown). However, late and short-term $\mathrm{T}_{\text {reg }}$ depletion caused only partial $\mathrm{T}_{\text {reg }}$ reduction, but the mice had significantly reduced dysplasia and OSCC at 24 weeks (Figures 4B, C, S6A). The frequencies of $\mathrm{CD}_{11 \mathrm{~b}^{+} \mathrm{Ly} 6 \mathrm{G}^{+} \text {and }}$ 

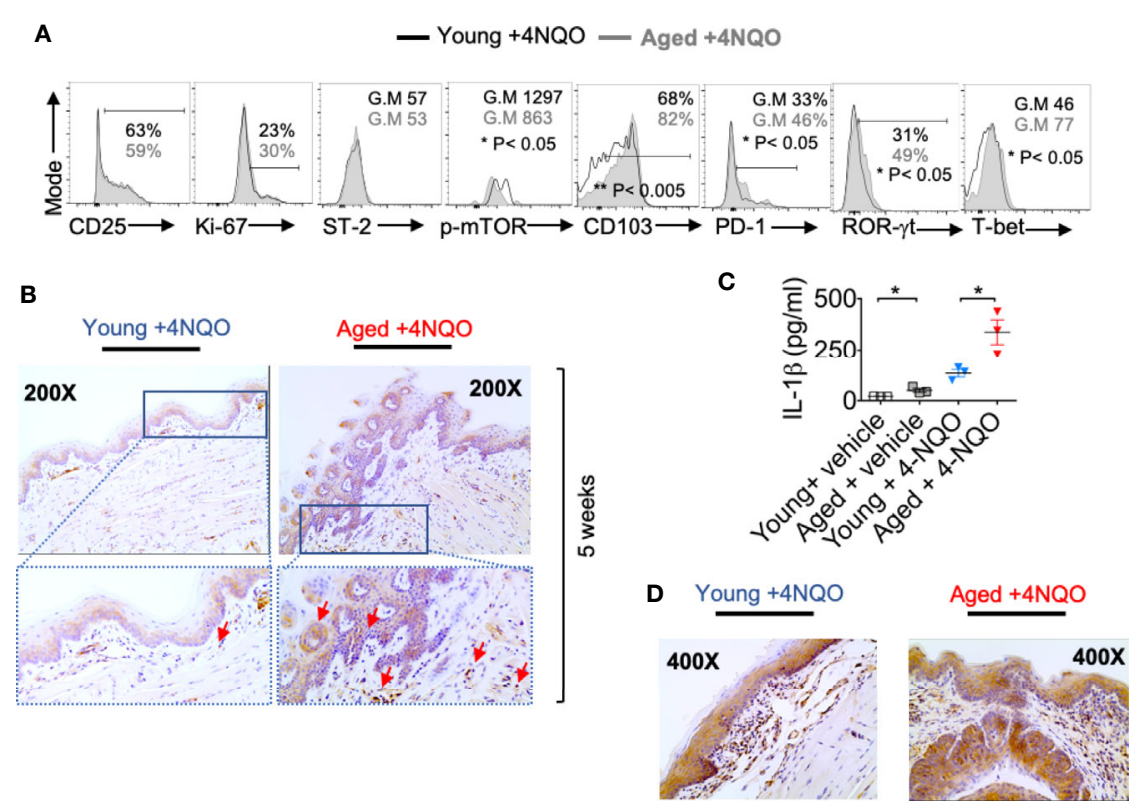

FIGURE 3 | Aged mice have distinct $\mathrm{T}_{\text {reg }}$ phenotype and elevated levels of IL-1 $\beta$ compared to young mice. 16 weeks after 4-NQO administration, single-cell suspension from tongue was re-stimulated with PMA/lonomycin for 4 hours. Flow cytometry histograms showing indicated protein expression in $\mathrm{CD}^{2} 5^{+} \mathrm{CD}^{+}$ CD $4^{+}$Foxp $3^{+}$cells (A). Tongue tissues were processed for IL-1 $\beta$ immuno-histochemical staining at 5 weeks (B). Supernatants collected at 12 weeks were processed for IL-1 $\beta$ ELISA. Mean $+/$ - SEM in 3 mice/group (Mann-Whitney test $\left.{ }^{*} \mathrm{P}<0.05\right)$ (C). Tongue tissues were processed for IL- $1 \beta$ immuno-histochemical staining at 24 weeks (D).

IL-1 $\beta^{+}$cells were unchanged with $\mathrm{T}_{\text {reg }}$ depletion, showing that these components are likely upstream to $\mathrm{T}_{\text {reg }}$ induction and infiltration during tumorigenesis (Figures S6B, C). However, the PD-1 expression was diminished and IFN- $\gamma$ expression was partially restored in $\mathrm{CD}^{+} \mathrm{T}$ cells (Figure $4 \mathrm{D}$ ). Collectively, these results show, for the first time in a 4-NQO OSCC model, that infiltrating $\mathrm{T}_{\text {regs }}$ control anti-tumorigenic functions of $\mathrm{CD} 8^{+}$ $\mathrm{T}$ cells and contribute to OSCC tumorigenesis and progression.

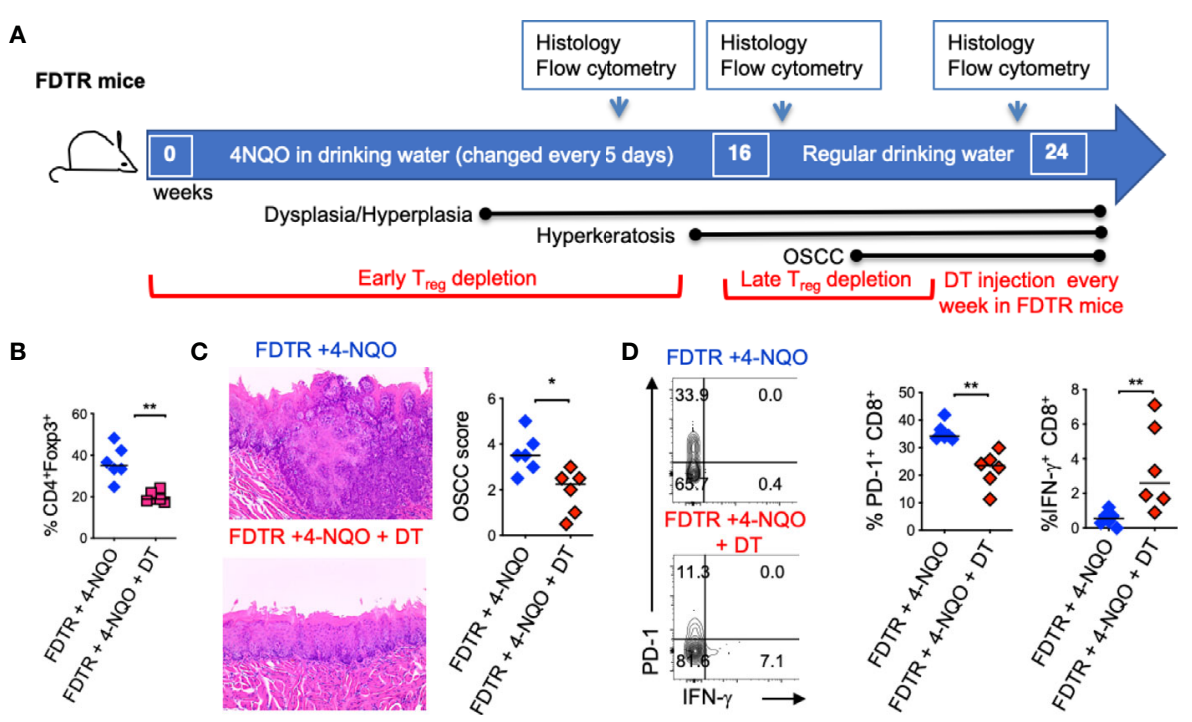

FIGURE 4 | Partial $T_{\text {reg }}$ depletion reduces tumor progression. $T_{\text {regs }}$ were depleted in FDTR mice by injecting diphtheria toxin (DT) at late time points (every 5 days between $16^{\text {th }}-21^{\text {st }}$ weeks of $4-\mathrm{NQO}$ treatment) (A). Statistics showing CD4 ${ }^{+}$Foxp3 $3^{+}$cells based on flow cytometry analyses at 20 and 24 weeks (B). Immunohistochemistry H\&E staining (left) and OSCC score based on invasive hyperkeratosis, and nesting (0-5) (right) (C). Contour plots (left) and statistics (right) showing PD-1 and IFN- $\gamma$ expressing CD8 ${ }^{+} T$ cells (D). Mean +/- SEM in 6 mice/group (Mann-Whitney test ${ }^{*} P<0.05,{ }^{* *} P<0.05$ ). 


\section{Candida and Zymosan Exacerbate and Accelerate Dysplasia and Hyperplasia}

Previous evidence has shown that oral carriage of Candida is higher in elderly individuals and patients with OSCC (47-51). We and others have previously shown that Candida infection can also induce IL-1 $\beta$ expression and $\mathrm{T}_{\text {reg }}$ infiltration in oral mucosa $(26,52)$. Since aforementioned results showed IL-1 $\beta$ was positively linked with tumorigenesis, we hypothesized that Candida infection and consequent IL- $1 \beta$ induction might worsen OSCC outcome. Therefore, we examined the effect of Candida infection and zymosan during carcinogenesis in 4-NQO treated mice. We sublingually applied Candida $\left(10^{7}\right.$ blastospores) or D-zymosan (TLR-2 depleted zymosan; $1 \mathrm{mg} /$ 100ul) under anesthesia WT or TLR-2 knockout (TLR-2 KO) C57BL/6 mice every week between $4^{\text {th }}$ and $8^{\text {th }}$ weeks of 4 -NQO administration. These treatments significantly accelerated and worsened dysplasia/hyperplasia (Figures 5A, B), increased IL$1 \beta^{+}$cells and $T_{\text {regs }}$ in the tongue at 12 weeks (Figures 5C, D, S7), and induced OSCC around 21 weeks (Figure 5E). Importantly, premature OSCC development was also observed in TLR-2 KO mice, revealing that zymosan and Candida mediated exacerbation of OSCC development was independent of TLR-2 signaling. In fact, in the absence of TLR-2, the numbers of IL-1 $\beta^{+}$ cells were increased implying the involvement of anti-fungal dectin-1 signaling in OSCC.

\section{Aged Mice Show Elevated Dectin-1 Signaling in Immune Cells in the Tongue and Increased Fungal Abundance in Saliva}

Dectin-1 is expressed by myeloid phagocytes (53) and binds specifically to fungal $\beta-1,3$ glucans, endogenous galectins, and annexins on apoptotic cells (54). Dectin1 signaling activation induces the phosphorylation of Syk and consequently the expression of IL-1 $\beta$. We and others have shown that dectin-1 signaling can regulate $\mathrm{T}_{\text {reg }}$ alterations and macrophage metabolism (55-58). Fungal dysbiosis and dectin-1 have also been implicated in inflammatory diseases and cancers (59-61). Thus, previous reports and our above-mentioned results led us to hypothesize that dectin-1 might be involved in OSCC development and earlier predisposition of aged mice to OSCC. Confirming the hypothesis, 4-NQO induced tumorigenesis promoted a significant elevation of dectin-1 expression and Syk activation in immune infiltrates $\left(\mathrm{CD} 45^{+}\right.$cells) (Figure 6A). Dectin-1 expression and Syk activation were further increased in aged 4-NQO treated mice suggesting the involvement of dectin-1 signaling in accelerated tumorigenesis in aging mice (Figure 6B). Although not-significant, there was also a trend towards increased fungal abundance in the saliva of 4-NQO treated mice, as measured by fungal abundance qPCR $(28,29)$. Interestingly, aged 4-NQO treated mice that displayed accelerated dysplasia and OSCC (Figure 1A), showed a
A

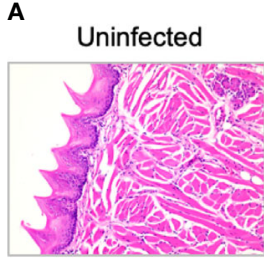

4-NQO

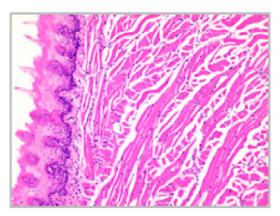

4-NQO+ Zymosan

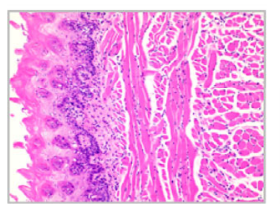

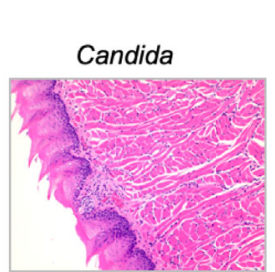

4-NQO + Candida

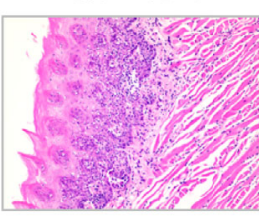

TLR-2 KO + 4-NQO + Candida + Zymosan

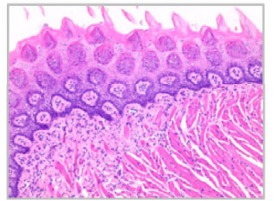

B

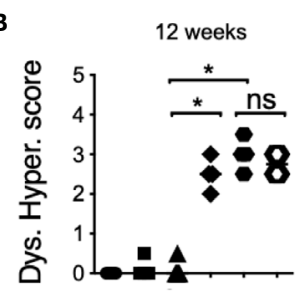

C

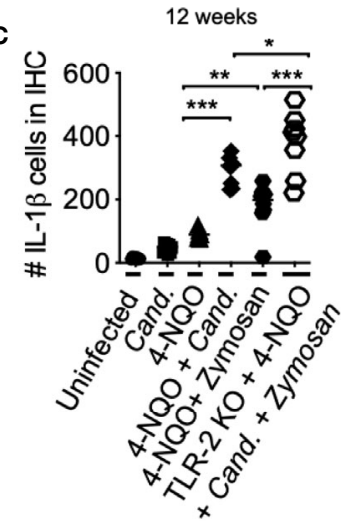

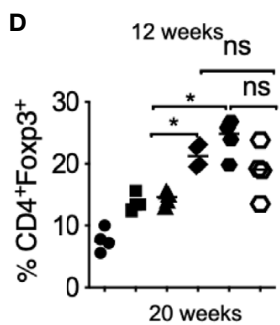

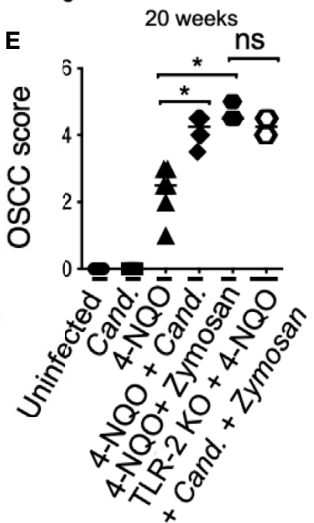

FIGURE 5 | Candida and Zymosan exacerbate and accelerate dysplasia and hyperplasia. (A) 4-NQO was administered in WT or TLR-2 KO C57BL/6 mice as in Figure $3 \mathbf{A}$ (6 mice/group). Zymosan ( $1 \mathrm{mg})$, Candida $\left(10^{7}\right.$ blastospores), or both were applied sublingually under anesthesia every week between the $4^{\text {th }}$ and $8^{\text {th }}$ weeks of 4-NQO administration. H\&E staining was performed to assess dysplasia and hyperplasia (A). Immunohistochemistry and flow cytometry were performed. Statistics based on dysplasia and hyperplasia score (B), IL-1 $\beta$ immunohistochemistry (C), flow cytometry staining for $\mathrm{T}_{\text {reg }}$ assessment (D), and OSCC scores (E). OSCC scores were assigned based on hyperplasia, invasive hyperkeratosis, and nests after 20 weeks after 4-NQO administration. Statistics show Mean +/- SEM (Mann-Whitney test ${ }^{\star} \mathrm{P}<0.05,{ }^{\star \star} \mathrm{P}<0.05,{ }^{* \star *} \mathrm{P}<0.005$, n.s, non-significant). 
A

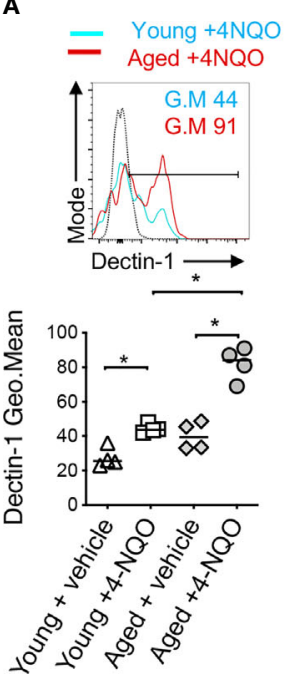

B

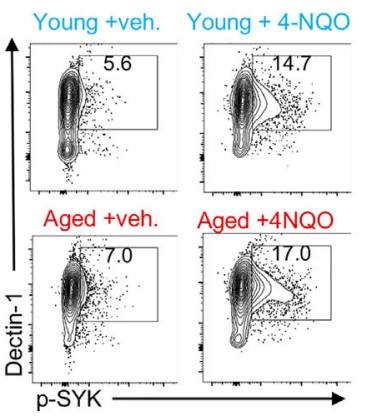

C

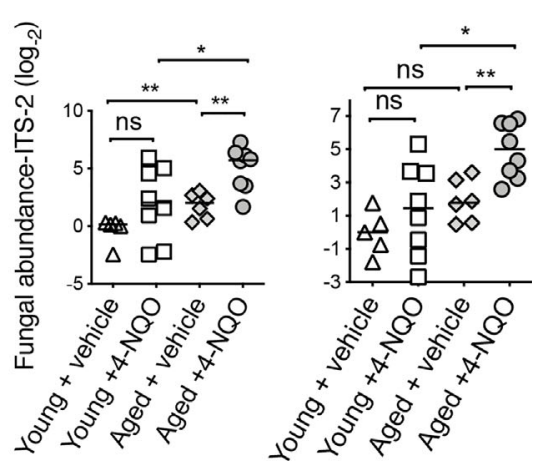

FIGURE 6 | Aged mice show elevated dectin-1 signaling in immune cells in the tongue and increased fungal abundance in saliva. Tongue samples were processed for flow cytometry. Contour plots (top) and statistics (bottom) showing dectin-1 expressing CD $45^{+}$cells (A). Contour plots showing \% of Dectin- $1^{+}$and phosphorylated SYK (p-SYK) expressing CD45 ${ }^{+}$cells (B). Saliva swabs collected at 12, 15, and 23 weeks were pooled. gPCR was performed to quantify fungal DNA using ITS-2 and fungi-quant PCR primers (C) $(28,29)$. Relative abundance was standardized to input DNA using $\beta$-actin as reference. (Mann-Whitney test $\left.{ }^{*} \mathrm{P}<0.05,{ }^{* *} \mathrm{P}<0.05\right)$.

significantly higher fungal abundance than control mice (Figure 6C). Together, these results revealed that increased fungal abundance and resultant aberrant dectin-1 signaling might play a role in accelerated tumorigenesis in aged mice.

\section{Dectin-1 Deficiency Reduces Immunosuppressive Cells and OSCC Tumor Burden}

Next, we investigated the role of dectin-1 in tumorigenesis using the mice deficient in dectin-1 signaling (Dectin KO mice). By monitoring body-weight we found that weight loss was much less pronounced in Dectin-1 KO than WT mice (Figure 7A). Dectin$1 \mathrm{KO}$ mice also had significantly reduced IL-1 $\beta^{+}$cells (Figure $7 \mathbf{B}$, S8), $\mathrm{T}_{\text {reg }}$ induction (Figure 7C, S9), $\mathrm{T}_{\text {reg }}$ : CD8 ratio (Figure 7D), PD- 1 induction in $\mathrm{CD}^{+} \mathrm{T}$ cells (Figures 7E, G), and MDSC cells (Figure 7F). However, coinciding with IFN- $\gamma$ restoration in CD8 $\mathrm{T}$ cells (Figures 7E, G), mice showed significantly slower progression of dysplasia and lower numbers and sizes of OSCC tumors (Figures 7H, I). Based on the phenotype of Dectin-1 KO mice, dectin-1 signaling appears to play a clear role in OSCC development. Taken together, these results show dectin-1 signaling is critical for establishing an immunosuppressive milieu and the development of oral tumorigenesis.

\section{DISCUSSION}

Aging skews host $\mathrm{CD} 4^{+} \mathrm{T}$ cells and $\mathrm{T}_{\text {regs }}$ towards an inflammatory $\mathrm{T}_{\text {reg }}$ type, which fails to control immunopathology during an infection. Instead, there is an increased accumulation of Foxp $3^{+}$ cells, a proportion of which is associated with increased $\mathrm{CD} 4^{+} \mathrm{T}$ cell hyperactivation and altered levels of IL- 6 and IL-1 $\beta$ in mice and humans in oral mucosa in vivo (26). To our knowledge, no study has examined $\mathrm{T}_{\text {reg }}$ interactions in TIME with relevance to aging and OSCC carcinogenesis. While there are contentious data on age-related changes in $\mathrm{T}_{\text {regs }}$ in blood $(62,63)$, there is no report to date on intra-tumoral $\mathrm{T}_{\text {regs }}$ and their interactions with other immune suppressive cells in the context of aging. In this study, we found that mouse and human OSCC tissues showed not only an increased accumulation of $\mathrm{T}_{\text {regs }}$ but also of MDSC. Moreover, aged mice showed increased and early filtration of these cells and were also more susceptible to early dysplasia and tumor development compared to young mice. The 4-NQO mouse model mimicked the multistage carcinogenesis of human OSCC so that we could investigate the immunological events in tumors and tumordraining lymph nodes in the early stages $(27,64)$. In this model, we found that infiltration of immunosuppressive cells was one of the early immunological events of OSCC initiation. We also validated these findings in developed human OSCC tumors, comparing them to adjacent normal control tissues. These data provided a compelling link among aging, immunosuppressive milieu, and oral cancer. While many previous studies have shown that high levels of intra-tumoral $\mathrm{T}_{\text {regs }}$ associate with poor prognosis, a few studies show that intra-tumoral $\mathrm{T}_{\text {regs }}$ in some cancers correlate with improved disease outcomes (65-68). However, multivariate analysis shows that $\mathrm{T}_{\text {reg }}$ levels are not independently prognostic of OSCC but cytolytic T cells that coinfiltrate along with $\mathrm{T}_{\text {regs }}$ appear to drive the favorable prognosis (15). Therefore we examined FOXP3 ${ }^{+}$cells in relation to $\mathrm{CD}^{+} \mathrm{T}$ cell frequency and MDSC. Increased intra-tumoral $\mathrm{T}_{\text {reg: }}$ CD8 ratio rather than increases in $\mathrm{T}_{\text {reg }}$ frequencies is more informative about 

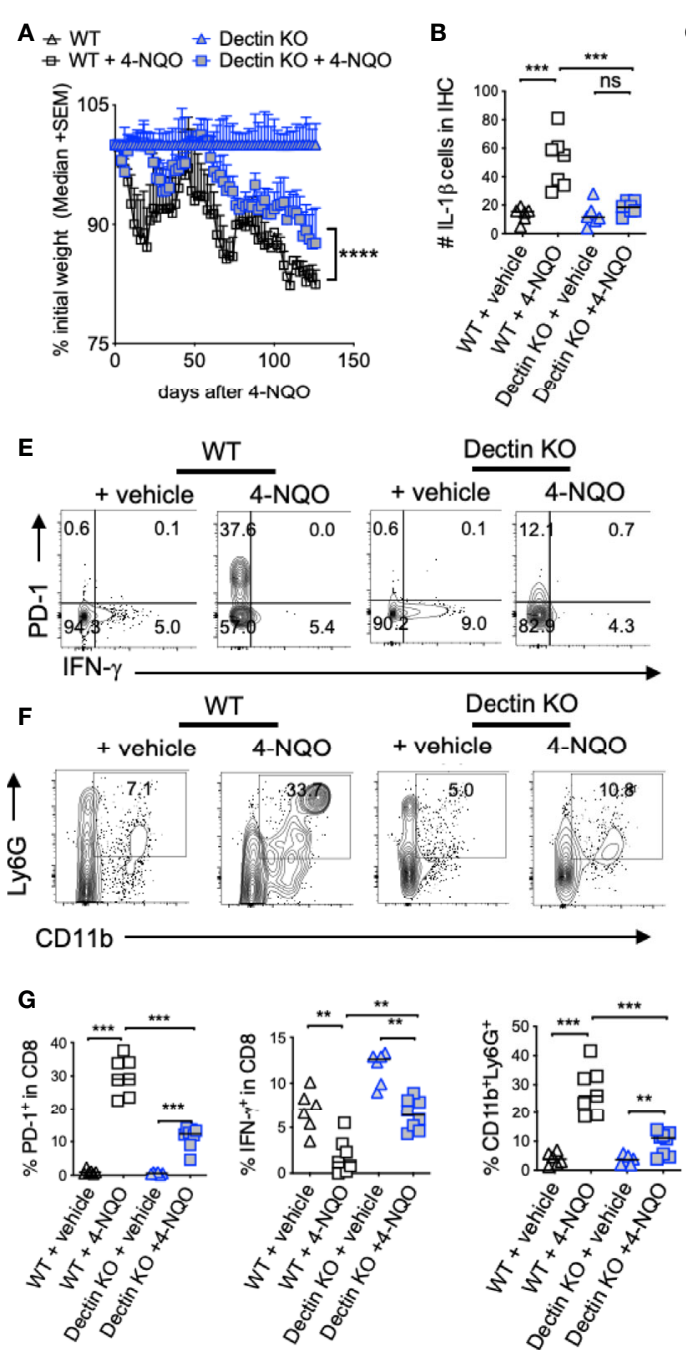
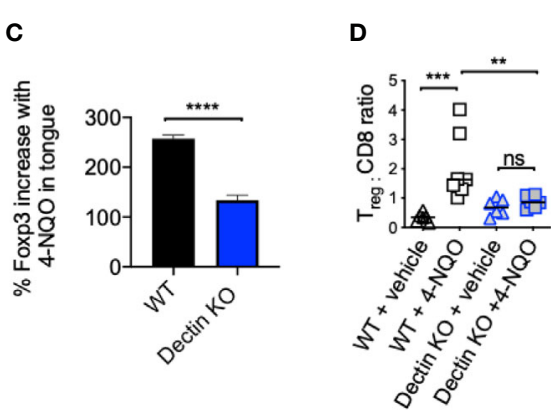

H
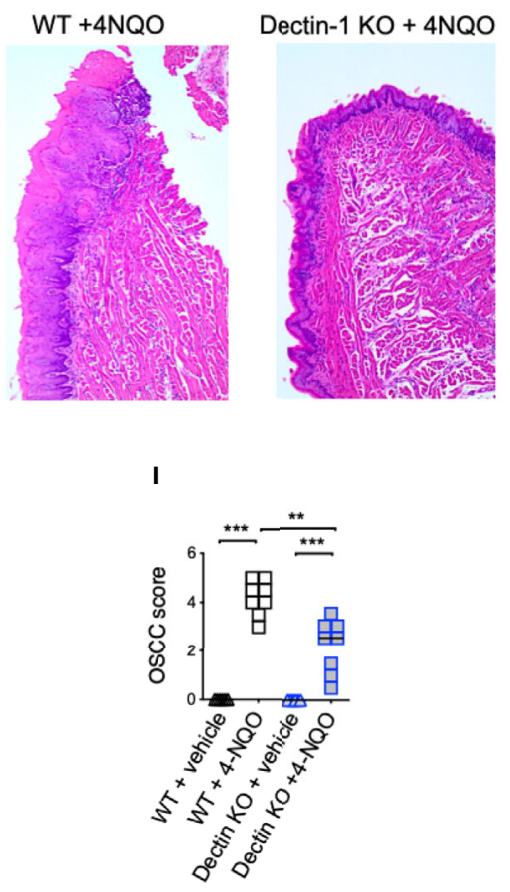

FIGURE 7 | Dectin-1 deficiency reduces immunosuppressive cells and OSCC tumor burden. Statistics showing the body weight loss, comparing the indicated groups (A). Tongue tissues were processed for immunohistochemistry (IHC) and flow cytometry at 23 weeks after 4-NQO administration. Statistics showing the number of IL-1 $\beta$ + cells in the entire field of $200 X I H C$ image (B). Flow cytometry-based statistics showing \% increase in $\mathrm{T}_{\text {regs }}$ in $4-\mathrm{NQO}$ treated mice compared to Veh. controls (C), $T_{\text {reg: }}$ :CD8 ratio (D), the \% of PD-1 and IFN- $\gamma$ expressing CD8 cells (E), the \% of CD11b and Ly6G expressing CD45 cells (F), and the statistical analysis for all of the above (G). H\&E immunohistochemistry of tongue (H), and blinded OSCC scoring (I). (Mann-Whitney test except for (B), where t-test with Welch's correction was performed, ${ }^{\star} \mathrm{P}<0.05$, ${ }^{\star \star} \mathrm{P}<0.05$, ${ }^{\star \star \star} \mathrm{P}<0.005$, ${ }^{\star \star \star \star} \mathrm{P}<0.0005$, n.s, non-significant).

pro-tumorigenic functions of $\mathrm{T}_{\text {regs }}$ during OSCC. Indeed, examining $\mathrm{T}_{\text {reg: }}$ CD8 ratio has allowed investigators to obtain consistent data showing clearly that a higher ratio is associated with poor prognosis and survival in human studies $(69,70)$. While we also characterized the $\mathrm{T}_{\text {regs }}$ by examining their inflammatory and tissue markers during early carcinogenesis in aging mice, more studies are required to determine the mechanisms underlying their altered phenotype and their contribution to OSCC development.

IL-1 $\beta$ is a cancer-associated pro-inflammatory cytokine that is abundant in breast, colon, lung, esophageal, as well as OSCC cancers (71). It is linked to poor prognosis for patients with esophageal cancer (72). Targeting IL-1 $\beta$ has been shown to hinder oral carcinogenesis in the 4-NQO model, and is considered in the clinical settings $(36,73)$. IL- $1 \beta$ is also involved in inducing immunomodulatory Foxp $3^{+} \mathrm{ROR}-\gamma \mathrm{t}^{+}$cells in microbiome dependent manner $(26,31,36,43,56,74-81)$. Foxp $3^{+}$ROR- $\gamma \mathrm{t}^{+}$cells have been shown to be present in tumors and contribute to tumor immune evasion and autoimmunity control $(35,82)$. But the events preceding excessive IL- $1 \beta$ expression and at the IL- $1 \beta / \mathrm{T}_{\text {reg }}$ interface are largely unknown. Our data showed that there was excessive IL-1 $\beta$ production in tongues of aged 4-NQO treated mice compared to young mice, demonstrating that IL-1 $\beta$ is clearly associated with the establishment of a worse immunosuppressive milieu. These results are distinct from an acute infection milieu and steady state-conditions where aging oral mucosa shows IL-1 $\beta$ suppression (26). Although it is conceivable that early 
carcinogenesis environment triggers elevated levels of IL-1 $\beta$ in aged mice, the sequence of events that promote elevated levels of IL-1 $\beta, T_{\text {reg }}$ accrual, and MDSC increase during aging need to be addressed. Furthermore, we found increased dectin-1 expression in immune infiltrates in aging mice. Also, signaling through dectin-1 promoted $\mathrm{T}_{\text {reg }}$ and MDSC accrual. While it is clear that immune cells show activation of Syk signaling, the precise subset of cells that responds through dectin-1 signaling hyperactivation in the context of aging remains to be addressed. While we hypothesize that changes in fungal stimulation emanating from the commensal fungal microbome could lead to dectin-1 activation, this possibility remains to be further confirmed in the future. The microbiome is a significant contributor to OSCC in the 4-NQO mediated carcinogenesis model $(83,84)$. Aging is also associated with changes in the resident microbiome, reduced microbiota diversity, and an increase in certain types of bacteria and fungi, resulting in local immunological changes, chronic inflammation, and other geriatric sequelae (85-87). Candida carriage and related co-morbidities are significantly more frequent in elderly individuals (88). The role of microbiome dysbiosis in enhancing dectin-1 signaling, immunosuppressive settings, and OSCC development, and how these are dysregulated during aging are critical questions to be addressed and will be studied in future investigations. Taken together, our study sheds new light on the immune-oncological events in TIME providing some key insights into mechanisms of immune evasion. By linking MDSC and $\mathrm{T}_{\text {regs }}$ with a higher predisposition of aged oral mucosa to tumor development, our study also provides important insights into mechanisms of higher susceptibility of the aging population to oral cancer. By revealing the pro-tumorigenic role of dectin-1 signaling and $\mathrm{T}_{\text {regs }}$, our study may also provide a way to control intratumoral $\mathrm{T}_{\text {regs }}$ without affecting the peripheral $\mathrm{T}_{\text {reg }}$ cell repertoire.

\section{DATA AVAILABILITY STATEMENT}

The original contributions presented in the study are included in the article/Supplementary Material. Further inquiries can be directed to the corresponding author.

\section{REFERENCES}

1. White MC, Holman DM, Goodman RA, Richardson LC. Cancer Risk Among Older Adults: Time for Cancer Prevention to Go Silver. Gerontologist (2019) 59:S1-6. doi: 10.1093/geront/gnz038

2. Harari Y, Kupiec M. Do Long Telomeres Affect Cellular Fitness? Curr Genet (2018) 64:173-6. doi: 10.1007/s00294-017-0746-Z

3. Jose SS, Bendickova K, Kepak T, Krenova Z, Fric J. Chronic Inflammation in Immune Aging: Role of Pattern Recognition Receptor Crosstalk With the Telomere Complex? Front Immunol (2017) 8:1078. doi: 10.3389/ fimmu.2017.01078

4. Scaffidi P, Misteli T. Lamin A-dependent Nuclear Defects in Human Aging. Science (2006) 312:1059-63. doi: 10.1126/science.1127168

5. Bronte V, Brandau S, Chen SH, Colombo MP, Frey AB, Greten TF, et al. Recommendations for Myeloid-Derived Suppressor Cell Nomenclature and Characterization Standards. Nat Commun (2016) 7:12150. doi: 10.1038/ ncomms 12150

\section{ETHICS STATEMENT}

The studies involving human participants were reviewed and approved by IRB. The patients/participants provided their written informed consent to participate in this study. The animal study was reviewed and approved by IACUC.

\section{AUTHOR CONTRIBUTIONS}

PP supervised the project, designed the study, performed experiments, analyzed data, and wrote the manuscript. QP and JT provided tumor resections from human participants under an approved protocol and contributed to discussions. NB and SJ performed the experiments and analyzed ELISA and qPCR data. PM weighed the mice and performed validation qPCRs. CQ and SJ performed microscopy of the histology slides, scored the histology data in a masked fashion, performed animal breeding, and processed tissues for flow cytometry. MG and AW read the manuscript and contributed to discussions. All authors contributed to the article and approved the submitted version.

\section{FUNDING}

PP was supported by the CWRU School of Dental Medicine departmental startup funding and Case Comprehensive Cancer Center- NIH Head and Neck Cancer SPORE pilot grant (P30 CA043703).

\section{SUPPLEMENTARY MATERIAL}

The Supplementary Material for this article can be found online at: https://www.frontiersin.org/articles/10.3389/fonc.2021. 669066/full\#supplementary-material

6. Grzywa TM, Sosnowska A, Matryba P, Rydzynska Z, Jasinski M, Nowis D, et al. Myeloid Cell-Derived Arginase in Cancer Immune Response. Front Immunol (2020) 11:938. doi: 10.3389/fimmu.2020.00938

7. Hatzioannou A, Banos A, Sakelaropoulos T, Fedonidis C, Vidali MS, Kohne M, et al. An Intrinsic Role of IL-33 in Treg Cell-Mediated Tumor Immunoevasion. Nat Immunol (2020) 21:75-85. doi: 10.1038/s41590-0190555-2

8. O'Higgins C, Ward FJ, Abu Eid R. Deciphering the Role of Regulatory Cd4 T Cells in Oral and Oropharyngeal Cancer: A Systematic Review. Front Oncol (2018) 8:442. doi: 10.3389/fonc.2018.00442

9. Onda M, Kobayashi K, Pastan I. Depletion of Regulatory T Cells in Tumors With an anti-CD25 Immunotoxin Induces CD8 T Cell-Mediated Systemic Antitumor Immunity. Proc Natl Acad Sci U S A (2019) 116:4575-82. doi: 10.1073/pnas.1820388116

10. Pandiyan P, Zheng L, Lenardo MJ. The Molecular Mechanisms of Regulatory T Cell Immunosuppression. Front Immunol (2011) 2:60. doi: 10.3389/ fimmu.2011.00060 
11. Sakaguchi S, Yamaguchi T, Nomura T, Ono M. Regulatory T Cells and Immune Tolerance. Cell (2008) 133:775-87. doi: 10.1016/j.cell.2008.05.009

12. Shevach EM. Mechanisms of Foxp3+ T Regulatory Cell-Mediated Suppression. Immunity (2009) 30:636-45. doi: 10.1016/j.immuni.2009.04.010

13. Chaudhry A, Rudensky AY. Control of Inflammation by Integration of Environmental Cues by Regulatory T Cells. J Clin Invest (2013) 123:939-44. doi: 10.1172/JCI57175

14. Gratz IK, Rosenblum MD, Abbas AK. The Life of Regulatory T Cells. Ann N Y Acad Sci (2013) 1283:8-12. doi: 10.1111/nyas.12011

15. Mandal R, Senbabaoglu Y, Desrichard A, Havel JJ, Dalin MG, Riaz N, et al. The Head and Neck Cancer Immune Landscape and its Immunotherapeutic Implications. JCI Insight (2016) 1:e89829. doi: 10.1172/jci.insight.89829

16. Tanchot C, Terme M, Pere H, Tran T, Benhamouda N, Strioga M, et al. Tumor-Infiltrating Regulatory T Cells: Phenotype, Role, Mechanism of Expansion in Situ and Clinical Significance. Cancer Microenviron (2013) 6:147-57. doi: 10.1007/s12307-012-0122-y

17. Nowicki TS, Hu-Lieskovan S, Ribas A. Mechanisms of Resistance to PD-1 and PDL1 Blockade. Cancer J (2018) 24:47-53. doi: 10.1097/PPO.0000000000000303

18. Wen L, Lu H, Li Q, Li Q, Wen S, Wang D, et al. Contributions of T Cell Dysfunction to the Resistance Against anti-PD-1 Therapy in Oral Carcinogenesis. J Exp Clin Cancer Res (2019) 38:299. doi: 10.1186/s13046019-1185-0

19. Tay C, Qian Y, Sakaguchi S. Hyper-Progressive Disease: The Potential Role and Consequences of T-Regulatory Cells Foiling Anti-Pd-1 Cancer Immunotherapy. Cancers (Basel) (2020) 13:1-19. doi: 10.3390/cancers13010048

20. Pang B, Zhen Y, Hu C, Ma Z, Lin S, Yi H. Myeloid-Derived Suppressor Cells Shift Th17/Treg Ratio and Promote Systemic Lupus Erythematosus Progression Through Arginase-1/miR-322-5p/TGF-beta Pathway. Clin Sci (Lond) (2020) 134:2209-22. doi: 10.1042/CS20200799

21. Pandiyan P, Lenardo MJ. The Control of CD4+CD25+Foxp3+ Regulatory T Cell Survival. Biol Direct (2008) 3:6. doi: 10.1186/1745-6150-3-6

22. Pierson W, Cauwe B, Policheni A, Schlenner SM, Franckaert D, Berges J, et al. Antiapoptotic Mcl-1 is Critical for the Survival and Niche-Filling Capacity of Foxp3(+) Regulatory T Cells. Nat Immunol (2013) 14:959-65. doi: 10.1038/ ni.2649

23. Barron L, Dooms H, Hoyer KK, Kuswanto W, Hofmann J, O'Gorman WE, et al. Cutting Edge: Mechanisms of IL-2-dependent Maintenance of Functional Regulatory T Cells. J Immunol (2010) 185:6426-30. doi: 10.4049/jimmunol.0903940

24. Tai X, Erman B, Alag A, Mu J, Kimura M, Katz G, et al. Foxp3 Transcription Factor is Proapoptotic and Lethal to Developing Regulatory T Cells Unless Counterbalanced by Cytokine Survival Signals. Immunity (2013) 38:1116-28. doi: 10.1016/j.immuni.2013.02.022

25. Wang X, Szymczak-Workman AL, Gravano DM, Workman CJ, Green DR, Vignali DA. Preferential Control of Induced Regulatory T Cell Homeostasis Via a Bim/Bcl-2 Axis. Cell Death Dis (2012) 3:e270. doi: 10.1038/cddis.2012.9

26. Bhaskaran N, Faddoul F, Paes da Silva A, Jayaraman S, Schneider E, Mamileti P, et al. IL-1beta-Myd88-Mtor Axis Promotes Immune-Protective Il-17a(+) Foxp3(+) Cells During Mucosal Infection and Is Dysregulated With Aging. Front Immunol (2020) 11:595936. doi: 10.3389/fimmu.2020.595936

27. Hasina R, Martin LE, Kasza K, Jones CL, Jalil A, Lingen MW. Abt-510 is an Effective Chemopreventive Agent in the Mouse 4-Nitroquinoline 1-Oxide Model of Oral Carcinogenesis. Cancer Prev Res (Phila) (2009) 2:385-93. doi: 10.1158/1940-6207.CAPR-08-0211

28. Iliev ID, Funari VA, Taylor KD, Nguyen Q, Reyes CN, Strom SP, et al. Interactions Between Commensal Fungi and the C-type Lectin Receptor Dectin-1 Influence Colitis. Science (2012) 336:1314-7. doi: 10.1126/ science. 1221789

29. Liu CM, Kachur S, Dwan MG, Abraham AG, Aziz M, Hsueh PR, et al. FungiQuant: A Broad-Coverage Fungal Quantitative Real-Time PCR Assay. BMC Microbiol (2012) 12:255. doi: 10.1186/1471-2180-12-255

30. Pandiyan P, Zheng L, Ishihara S, Reed J, Lenardo MJ. Cd4(+)Cd25(+)Foxp3 (+) Regulatory T Cells Induce Cytokine Deprivation-Mediated Apoptosis of Effector CD4(+) T Cells. Nat Immunol (2007) 8:1353-62. doi: 10.1038/ni1536

31. Bhaskaran N, Quigley C, Paw C, Butala S, Schneider E, Pandiyan P. Role of Short Chain Fatty Acids in Controlling Tregs and Immunopathology During Mucosal Infection. Front Microbiol (2018) 9:1995. doi: 10.3389/ fmicb.2018.01995
32. Pandiyan P, Conti HR, Zheng L, Peterson AC, Mathern DR, HernandezSantos N, et al. Cd4(+)Cd25(+)Foxp3(+) Regulatory T Cells Promote Th17 Cells In Vitro and Enhance Host Resistance in Mouse Candida Albicans Th17 Cell Infection Model. Immunity (2011) 34:422-34. doi: 10.1016/ j.immuni.2011.03.002

33. Bhaskaran N, Weinberg A, Pandiyan P. Th17 Inflammation Model of Oropharyngeal Candidiasis in Immunodeficient Mice. J Visualized Experiments JoVE (2015) 96:1-12. doi: 10.3791/52538

34. Vincent-Chong VK, DeJong H, Rich LJ, Patti A, Merzianu M, Hershberger PA, et al. Impact of Age on Disease Progression and Microenvironment in Oral Cancer. J Dent Res (2018) 97:1268-76. doi: 10.1177/0022034518775736

35. Downs-Canner S, Berkey S, Delgoffe GM, Edwards RP, Curiel T, Odunsi K, et al. Suppressive IL-17A(+)Foxp3(+) and Ex-Th17 IL-17A(neg)Foxp3(+) Treg Cells are a Source of Tumour-Associated Treg Cells. Nat Commun (2017) 8:14649. doi: 10.1038/ncomms14649

36. Wu T, Hong Y, Jia L, Wu J, Xia J, Wang J, et al. Modulation of IL-1beta Reprogrammes the Tumor Microenvironment to Interrupt Oral Carcinogenesis. Sci Rep (2016) 6:20208. doi: 10.1038/srep20208

37. Saito T, Nishikawa H, Wada H, Nagano Y, Sugiyama D, Atarashi K, et al. Two Foxp3(+)Cd4(+) T Cell Subpopulations Distinctly Control the Prognosis of Colorectal Cancers. Nat Med (2016) 22:679-84. doi: 10.1038/nm.4086

38. Chu M, Su YX, Wang L, Zhang TH, Liang YJ, Liang LZ, et al. Myeloid-Derived Suppressor Cells Contribute to Oral Cancer Progression in 4NQO-Treated Mice. Oral Dis (2012) 18:67-73. doi: 10.1111/j.1601-0825.2011.01846.x

39. Arpaia N, Green JA, Moltedo B, Arvey A, Hemmers S, Yuan S, et al. A Distinct Function of Regulatory T Cells in Tissue Protection. Cell (2015) 162:1078-89. doi: 10.1016/j.cell.2015.08.021

40. Pandiyan P, Younes S, Ribeiro S, Talla A, Bhaskaran N, McDonald D, et al. Mucosal Regulatory T Cells and T Helper 17 Cells in HIV Associated Immune Activation. Front Immunol (2016) 7:228. doi: 10.3389/fimmu.2016.00228

41. Weinberg A, Tugizov S, Pandiyan P, Jin G, Rakshit S, Vyakarnam A, et al. Innate Immune Mechanisms to Oral Pathogens in Oral Mucosa of HIVinfected Individuals. Oral Dis (2020) 26(Suppl 1):69-79. doi: 10.1111/ odi. 13470

42. Younes SA, Talla A, Pereira Ribeiro S, Saidakova EV, Korolevskaya LB, Shmagel KV, et al. Cycling Cd4+ T Cells in HIV-infected Immune Nonresponders Have Mitochondrial Dysfunction. J Clin Invest (2018) 128:5083-94. doi: 10.1172/JCI120245

43. Pandiyan P, Bhaskaran N, Zou M, Schneider E, Jayaraman S, Huehn J. Microbiome Dependent Regulation of Tregs and Th17 Cells in Mucosa. Front Immunol (2019) 3:78-94. doi: 10.3389/fimmu.2019.00426

44. Lowther DE, Goods BA, Lucca LE, Lerner BA, Raddassi K, van Dijk D, et al. PD-1 Marks Dysfunctional Regulatory T Cells in Malignant Gliomas. JCI Insight (2016) 1:1-15. doi: 10.1172/jci.insight.85935

45. Levine AG, Mendoza A, Hemmers S, Moltedo B, Niec RE, Schizas M, et al. Stability and Function of Regulatory T Cells Expressing the Transcription Factor T-Bet. Nature (2017) 546:421-5. doi: 10.1038/nature22360

46. Duhen T, Duhen R, Montler R, Moses J, Moudgil T, de Miranda NF, et al. CoExpression of CD39 and CD103 Identifies Tumor-Reactive CD8 T Cells in Human Solid Tumors. Nat Commun (2018) 9:2724. doi: 10.1038/s41467-01805072-0

47. Perera M, Al-Hebshi NN, Perera I, Ipe D, Ulett GC, Speicher DJ, et al. A Dysbiotic Mycobiome Dominated by Candida Albicans is Identified Within Oral Squamous-Cell Carcinomas. J Oral Microbiol (2017) 9:1385369. doi: 10.1080/20002297.2017.1385369

48. Bastiaan RJ, Reade PC. The Prevalence of Candida Albicans in the Mouths of Tobacco Smokers With and Without Oral Mucous Membrane Keratoses. Oral Surg Oral Med Oral Pathol (1982) 53:148-51. doi: 10.1016/0030-4220(82) 90280-8

49. Cawson RA. Leukoplakia and Oral Cancer. Proc R Soc Med (1969) 62:610-5 doi: 10.1177/003591576906200637

50. Dwivedi PP, Mallya S, Dongari-Bagtzoglou A. A Novel Immunocompetent Murine Model for Candida Albicans-Promoted Oral Epithelial Dysplasia. Med Mycol (2009) 47:157-67. doi: 10.1080/13693780802165797

51. O'Grady JF, Reade PC. Candida Albicans as a Promoter of Oral Mucosal Neoplasia. Carcinogenesis (1992) 13:783-6. doi: 10.1093/carcin/13.5.783

52. Cheng SC, van de Veerdonk FL, Lenardon M, Stoffels M, Plantinga T, Smeekens S, et al. The dectin-1/inflammasome Pathway is Responsible for 
the Induction of Protective T-helper 17 Responses That Discriminate Between Yeasts and Hyphae of Candida Albicans. J Leukoc Biol (2011) 90:357-66. doi: 10.1189/jlb.1210702

53. Inoue M, Shinohara ML. Clustering of Pattern Recognition Receptors for Fungal Detection. PLoS Pathog (2014) 10:e1003873. doi: 10.1371/journal.ppat.1003873

54. Bode K, Bujupi F, Link C, Hein T, Zimmermann S, Peiris D, et al. Dectin-1 Binding to Annexins on Apoptotic Cells Induces Peripheral Immune Tolerance Via NADPH Oxidase-2. Cell Rep (2019) 29:4435-46.e9. doi: 10.1016/j.celrep.2019.11.086

55. Bhaskaran N, Cohen S, Zhang Y, Weinberg A, Pandiyan P. Tlr-2 Signaling Promotes IL-17A Production in CD4+CD25+Foxp3+ Regulatory Cells During Oropharyngeal Candidiasis. Pathogens (2015) 4:90-110. doi: $10.3390 /$ pathogens 4010090

56. Pandiyan P, Zhu J. Origin and Functions of Pro-Inflammatory Cytokine Producing Foxp3(+) Regulatory T Cells. Cytokine (2015) 76:13-24. doi: 10.1016/j.cyto.2015.07.005

57. Osorio F, LeibundGut-Landmann S, Lochner M, Lahl K, Sparwasser T, Eberl G, et al. DC Activated Via Dectin-1 Convert Treg Into IL-17 Producers. Eur J Immunol (2008) 38:3274-81. doi: 10.1002/eji.200838950

58. Cheng SC, Quintin J, Cramer RA, Shepardson KM, Saeed S, Kumar V, et al. mTOR- and HIF-1alpha-mediated Aerobic Glycolysis as Metabolic Basis for Trained Immunity. Science (2014) 345:1250684. doi: 10.1126/science.1250684

59. Daley D, Mani VR, Mohan N, Akkad N, Ochi A, Heindel DW, et al. Dectin 1 Activation on Macrophages by Galectin 9 Promotes Pancreatic Carcinoma and Peritumoral Immune Tolerance. Nat Med (2017) 23:556-67. doi: 10.1038/nm.4314

60. Iliev ID, Leonardi I. Fungal Dysbiosis: Immunity and Interactions At Mucosal Barriers. Nat Rev Immunol (2017) 17:635-46. doi: 10.1038/nri.2017.55

61. Wang T, Fan C, Yao A, Xu X, Zheng G, You Y, et al. The Adaptor Protein CARD9 Protects Against Colon Cancer by Restricting Mycobiota-Mediated Expansion of Myeloid-Derived Suppressor Cells. Immunity (2018) 49:50414.e4. doi: 10.1016/j.immuni.2018.08.018

62. Harpaz I, Bhattacharya U, Elyahu Y, Strominger I, Monsonego A. Old Mice Accumulate Activated Effector Cd4 T Cells Refractory to Regulatory T CellInduced Immunosuppression. Front Immunol (2017) 8:283. doi: 10.3389/ fimmu.2017.00283

63. Hwang KA, Kim HR, Kang I. Aging and Human CD4(+) Regulatory T Cells. Mech Ageing Dev (2009) 130:509-17. doi: 10.1016/j.mad.2009.06.003

64. Lee CH, Chang JS, Syu SH, Wong TS, Chan JY, Tang YC, et al. Il-1beta Promotes Malignant Transformation and Tumor Aggressiveness in Oral Cancer. J Cell Physiol (2015) 230:875-84. doi: 10.1002/jcp.24816

65. de Ruiter EJ, Ooft ML, Devriese LA, Willems SM. The Prognostic Role of Tumor Infiltrating T-lymphocytes in Squamous Cell Carcinoma of the Head and Neck: A Systematic Review and Meta-Analysis. Oncoimmunology (2017) 6:e1356148. doi: 10.1080/2162402X.2017.1356148

66. Santegoets SJ, Duurland CL, Jordanova ES, van Ham JJ, Ehsan I, van Egmond $\mathrm{SL}$, et al. Tbet-Positive Regulatory $\mathrm{T}$ Cells Accumulate in Oropharyngeal Cancers With Ongoing Tumor-Specific Type $1 \mathrm{~T}$ Cell Responses. J Immunother Cancer (2019) 7:14. doi: 10.1186/s40425-019-0497-0

67. Takeuchi Y, Nishikawa H. Roles of Regulatory T Cells in Cancer Immunity. Int Immunol (2016) 28:401-9. doi: 10.1093/intimm/dxw025

68. Stasikowska-Kanicka O, Wagrowska-Danilewicz M, Danilewicz M. Immunohistochemical Analysis of Foxp3(+), Cd4(+), CD8(+) Cell Infiltrates and PD-L1 in Oral Squamous Cell Carcinoma. Pathol Oncol Res (2018) 24:497-505. doi: 10.1007/s12253-017-0270-y

69. Sato E, Olson SH, Ahn J, Bundy B, Nishikawa H, Qian F, et al. Intraepithelial CD8+ Tumor-Infiltrating Lymphocytes and a High CD8+/Regulatory T Cell Ratio are Associated With Favorable Prognosis in Ovarian Cancer. Proc Natl Acad Sci U S A (2005) 102:18538-43. doi: 10.1073/pnas.0509182102

70. Watanabe Y, Katou F, Ohtani H, Nakayama T, Yoshie O, Hashimoto K. Tumor-Infiltrating Lymphocytes, Particularly the Balance Between CD8(+) T Cells and CCR4(+) Regulatory T Cells, Affect the Survival of Patients With Oral Squamous Cell Carcinoma. Oral Surg Oral Med Oral Pathol Oral Radiol Endod (2010) 109:744-52. doi: 10.1016/j.tripleo.2009.12.015

71. Shiiba M, Saito K, Yamagami H, Nakashima D, Higo M, Kasamatsu A, et al. Interleukin-1 Receptor Antagonist (IL1RN) is Associated With Suppression of Early Carcinogenic Events in Human Oral Malignancies. Int J Oncol (2015) 46:1978-84. doi: 10.3892/ijo.2015.2917
72. Chen MF, Lu MS, Chen PT, Chen WC, Lin PY, Lee KD. Role of Interleukin 1 Beta in Esophageal Squamous Cell Carcinoma. J Mol Med (Berl) (2012) 90:89100. doi: 10.1007/s00109-011-0809-4

73. Dinarello CA. Why Not Treat Human Cancer With Interleukin-1 Blockade? Cancer Metastasis Rev (2010) 29:317-29. doi: 10.1007/s10555-010-9229-0

74. Landskron G, De la Fuente M, Thuwajit P, Thuwajit C, Hermoso MA. Chronic Inflammation and Cytokines in the Tumor Microenvironment. J Immunol Res (2014) 2014:149185. doi: 10.1155/2014/149185

75. El-Omar EM, Carrington M, Chow WH, McColl KE, Bream JH, Young HA, et al. Interleukin-1 Polymorphisms Associated With Increased Risk of Gastric Cancer. Nature (2000) 404:398-402. doi: 10.1038/35006081

76. Hulkkonen J, Vilpo J, Vilpo L, Koski T, Hurme M. Interleukin-1 Beta, Interleukin-1 Receptor Antagonist and Interleukin-6 Plasma Levels and Cytokine Gene Polymorphisms in Chronic Lymphocytic Leukemia: Correlation With Prognostic Parameters. Haematologica (2000) 85:600-6.

77. Li L, Boussiotis VA. The Role of IL-17-producing Foxp3+ Cd4+ T Cells in Inflammatory Bowel Disease and Colon Cancer. Clin Immunol (2013) 148:246-53. doi: 10.1016/j.clim.2013.05.003

78. Li L, Kim J, Boussiotis VA. Il-1beta-mediated Signals Preferentially Drive Conversion of Regulatory T Cells But Not Conventional T Cells Into IL-17producing Cells. J Immunol (2010) 185:4148-53. doi: 10.4049/jimmunol.1001536

79. Li L, Patsoukis N, Petkova V, Boussiotis VA. Runx1 and Runx3 are Involved in the Generation and Function of Highly Suppressive IL-17-Producing T Regulatory Cells. PLoS One (2012) 7:e45115. doi: 10.1371/journal.pone.0045115

80. Miyao T, Floess S, Setoguchi R, Luche H, Fehling HJ, Waldmann H, et al. Plasticity of Foxp3(+) T Cells Reflects Promiscuous Foxp3 Expression in Conventional T Cells But Not Reprogramming of Regulatory T Cells. Immunity (2012) 36:262-75. doi: 10.1016/j.immuni.2011.12.012

81. Sefik E, Geva-Zatorsky N, Oh S, Konnikova L, Zemmour D, McGuire AM, et al. Mucosal IMMUNOLOGY. Individual Intestinal Symbionts Induce a Distinct Population of RORgamma(+) Regulatory T Cells. Science (2015) 349:993-7. doi: 10.1126/science.aaa9420

82. Kim BS, Lu H, Ichiyama K, Chen X, Zhang YB, Mistry NA, et al. Generation of RORgammat(+) Antigen-Specific T Regulatory 17 Cells From Foxp3(+) Precursors in Autoimmunity. Cell Rep (2017) 21:195-207. doi: 10.1016/ j.celrep.2017.09.021

83. Stashenko P, Yost S, Choi Y, Danciu T, Chen T, Yoganathan S, et al. The Oral Mouse Microbiome Promotes Tumorigenesis in Oral Squamous Cell Carcinoma. mSystems (2019) 4. doi: 10.1128/mSystems.00323-19

84. Wu JS, Zheng M, Zhang M, Pang X, Li L, Wang SS, et al. Porphyromonas Gingivalis Promotes 4-Nitroquinoline-1-Oxide-Induced Oral Carcinogenesis With an Alteration of Fatty Acid Metabolism. Front Microbiol (2018) 9:2081. doi: $10.3389 /$ fmicb.2018.02081

85. Buford TW. (Dis)Trust Your Gut: The Gut Microbiome in Age-Related Inflammation, Health, and Disease. Microbiome (2017) 5:80. doi: 10.1186/ s40168-017-0296-0

86. Clark RI, Walker DW. Role of Gut Microbiota in Aging-Related Health Decline: Insights From Invertebrate Models. Cell Mol Life Sci (2018) 75:93101. doi: 10.1007/s00018-017-2671-1

87. Zapata HJ, Quagliarello VJ. The Microbiota and Microbiome in Aging: Potential Implications in Health and Age-Related Diseases. J Am Geriatr Soc (2015) 63:776-81. doi: 10.1111/jgs.13310

88. Barchiesi F, Orsetti E, Mazzanti S, Trave F, Salvi A, Nitti C, et al. Candidemia in the Elderly: What Does it Change? PLoS One (2017) 12:e0176576. doi: 10.1371/journal.pone.0176576

Conflict of Interest: The authors declare that the research was conducted in the absence of any commercial or financial relationships that could be construed as a potential conflict of interest.

Copyright $\odot 2021$ Bhaskaran, Jayaraman, Quigley, Mamileti, Ghannoum, Weinberg, Thuener, Pan and Pandiyan. This is an open-access article distributed under the terms of the Creative Commons Attribution License (CC BY). The use, distribution or reproduction in other forums is permitted, provided the original author(s) and the copyright owner(s) are credited and that the original publication in this journal is cited, in accordance with accepted academic practice. No use, distribution or reproduction is permitted which does not comply with these terms. 